\author{
Journal of Asian Scientific Research \\ $\operatorname{ISSN}(e): \quad 2223-1331$ \\ $\operatorname{ISSN}(p): \quad 2226-5724$ \\ DOI: $10.18488 /$ journal.2.2020.104.238.254 \\ Vol. 10, No. 4, 238-254. \\ (C) 2020 AESS Publications. All Rights Reserved. \\ URL: wrw.aessweb.com \\ check for
updates
}

\title{
THE IMPACT OF HUMAN RESOURCES MANAGEMENT PRACTICES AS AN ENTRY POINT IN CRISIS MANAGEMENT
}

\author{
Wail Shafi \\ lshammari ${ }^{1}$ \\ Ahmad Saleh \\ Alhazaimeh $^{2+}$ \\ Mohammad Omar \\ Alzoubi ${ }^{3}$
}

\author{
${ }^{1,2}$ Department of Public Administration Faculty of Economics $\varepsilon^{\circ}$ \\ Administration, King Abdulaziz University, Saudi Arabia. \\ 'Email: rusalshammari@kau.edu.saTel:00966541102509 \\ ¿Email:amefleh@kau.edu.sa Tel:00966532200551 \\ ${ }^{s}$ Department of Administrative Sciences Faculty of Business, Jerash \\ University, Jordan. \\ sEmail:alzoubimoh64@yahoo.in Tel:00962786534452
}

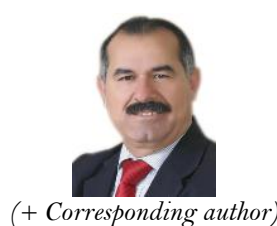

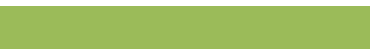

Article History

Received: 26 June 2020 Revised: 29 July 2020 Accepted: 31 August 2020

Published: 24 September 2020

\section{Keywords}

Human resources management (HRM)

Crisis management

Jordanian commercial banks

Warning signals

Damage containment

Learning

Readiness and prevention

\begin{abstract}
This study aimed to explore the impact of human resources management practices (training, participating in decision-making, motivation, and controlling), trying to build theoretical and practical frame for the effect of human resource practices in fulfilling innovations. And trying to clarify the impact of these practices on crisis management. In addition to introduce suggestions and recommendations to the firms, and to future research in similar topics. The population consisted of the estimated 11 commercial bank employees, operating in Irbid province, out of a total 34 branches, and a randomized judgmental sample were taken from (80) employees working in human resources departments. (71) resolutions deemed fit for analysis recovered. The most important research findings that there is positive statistically significant influence for human resources management practices (training, participating in decision-making, motivation, and controlling)) in crisis management. The study recommends that outsourcing like consultants is another option, consultant that can lead the process.
\end{abstract}

Contribution/ Originality This study aimed to explore the impact of human resources management practices (training, participating in decision-making, motivation, and controlling), trying to build theoretical and practical frame for the effect of human resource practices in fulfilling innovations.

\section{INTRODUCTION}

Human resources management occupy the main position in attention as the most important element and pillars of development, and the basis of moving the wheels of growth and development and the countries of the developed and developing world, human resources are the basic wealth in any service or productive organization, it is the most important element of production.

Human resources management practices are one of the important means used by organizations to increase their efficiency and effectiveness and to cope with the crises they face, depending primarily on the success or failure of the organizations' efforts in achieving their objectives, namely survival, stability, expansion, growth, productivity, improvement of services and the achievement of the necessary advantage for this era of different environmental variables. 
An effective Human resources management practices help the flow of job among different parties, between organizations and different countries, and lead to improve and strengthen the relations with customers and suppliers.

The organizations work in complex and uncertain environment, and these environments exposed to change suddenly without any alarm, the good and success organization should be alert to these changes and be ready. Human resources play a key role in the success of the organizations.

Human Resources Management: Is a series of decisions about functional relationships affecting the effectiveness of the organization and employees, namely the design and preparation of the objectives, policies and activities of human resources management in a way that achieves harmony with other administrative objectives in the organization.

Crises: are a problem for institutions seeking to grow and continue in the business world, and the crisis results from environmental changes that generate a degree of risk and threat that requires quick decisions to contain them, and needs proper planning to try to overcome the crisis or minimize its negative effects. The best that can be done in this regard is for administrators and workers to remain on constant alert and prepared, ready to do their best to cope with the crisis by training to deal with crises by creating a crisis and using a simulation system commensurate with the requirements of dealing with the crisis, and this of course calls for an effective human resource practices based on knowledge and good training systems.

The term crisis management was first used in international political relations in 1962 when the Soviet missile crisis erupted on Cuban territory, which exacerbated relations between Moscow and Washington to the point where U.S. President John F. Kennedy was threatened with a third world war. But the crisis ended with Russian leader Khrushchev agreeing to dismantle the missiles in exchange for a US pledge not to invade Cuba. McNamara, then Secretary of Defense of the United States, said that the era of (strategy) was over and a new era began, which we might call the crisis management era.

\section{PROBLEM AND QUESTIONS OF THE STUDY}

Individuals, societies and nations face many crises that plague the future of their lives and sometimes threaten their entire existence, especially in our Arab societies, which lack infrastructure, from strategic plans and material and human possibilities to face those crises. Commercial banks operate in a highly complex and competitive environment, and their success often depends on their ability to keep up with developments, which requires them to adapt to rapid environmental changes, because their ability to monitor changes in the environment, which are often complex, changing and environmentally unconfirmed, help them adapt to this environment. The issue of how to deal with crises becomes inevitable and inevitable.

For banks to deal with crises, they have to be ready to the crisis before it occurs, and in a timely manner. The human resources practices should therefore have led to the provision of all management levels of procedures according to their specialties, and that these procedures will be useful.

The lack of adequate human resources group for these commercial banks to monitor changes in the environment can lead to frequent crises, so the problem of this study is knowing how effective the HRM practices used in banks are in dealing with the crises.

The problem of study can be expressed by asking: How well do the organization understand the importance of human resources management practices? (training, participating in decision-making, motivation, controlling, resource conservation) as an entry point for crisis management in banks.

\section{THE OBJECTIVES OF THE STUDY}

1. To identify the reality of applying the concept of crisis management by commercial banks in Jordan/ Northern Sector. 
2. To identify the impact human resources management practices (training, participating in decision-making, motivation, and controlling) as an entry point in crisis management.

3. It deals with an important economic sector (the commercial banking sector), which is one of the sectors facing various crises.

4. This study adds a theoretical dimension in crisis management in the commercial banking sector.

5. To introduce the concept of human resources management practices and the levels of availability of these practices in Jordanian commercial banks.

6. To learn how to invest human resources management practices and their role in raising the level of crisis management in Jordanian commercial banks.

\section{THE IMPORTANCE OF THE STUDY}

The importance of the study is reflected in the fact that it seeks to clarify the relationship between the role of human resources management practices in raising the level of crisis management in commercial banks in Jordan, achieving the satisfaction of the provider and recipients of the service, and providing a systematic vision about the most important practices related to human resources. By studying the following human resources elements: (training, participation in decision-making, motivation, controlling).

\section{HYPOTHESES OF THE STUDY}

The main hypothesis: There is no statistically significant effect for the human resources management practices (training, participation in decision-making, motivation, controlling) in the ability of Jordanian commercial banks in manage crises (Readiness and prevention, damage containment, Reactivity, Learning).

Hypothesis 1: there is no statistically significant effect for the training in the ability of Jordanian commercial banks in manage crises.

Hypothesis 2: There is no statistically significant effect for the participation in decision making in the ability of Jordanian commercial banks in manage crises.

Hypothesis 3: there is no statistically significant effect for the motivation in the ability of Jordanian commercial banks in manage crises.

Hypothesis 4: There is no statistically significant effect for Controlling in the ability of Jordanian commercial banks in manage crises.

\section{PROCEDURAL DEFINITIONS}

Human resources management practices: (HRMp) have been defined as a series of decisions about career relationships affecting the organizations and staff effectiveness [1].

Crisis: The final result of the accumulation of a combination of influences or a sudden malfunction affecting the main components of the system, and posing a clear and obvious threat to the survival of the organization or system itself $[2]$.

Jordanian Commercial Banks: A facility whose main operations are to mobilize financial resources and money that are surplus to the needs of the public and institutions in the form of savings for the purpose of lending and employing by others in accordance with the rules and methods involved [3].

Jordanian commercial banks are listed in the Central Bank and the Jordanian Securities Exchange and are described in Appendix A.

\section{THE METHODOLOGY OF THE STUDY}

This study is a practical study on Jordanian commercial banks which is consistent with the analytical approach. 
Independent variables

\begin{tabular}{|c|c|}
\hline $\begin{array}{l}\text { Human resources management } \\
\text { practices }\end{array}$ & Crisis Management \\
\hline $\begin{array}{l}\text { - } \text { the training } \\
\text { - } \text { the participation in decision } \\
\text { making } \\
\text { - } \text { the motivation } \\
\text { - Controlling }\end{array}$ & $\begin{array}{l}\text { - Detecting warning signal } \\
\text { - Readiness and prevention } \\
\text { - Damage containment } \\
- \text { Reactivity } \\
-\quad \text { Learning }\end{array}$ \\
\hline
\end{tabular}

Figure-1. The model of the study.

\subsection{The Community and the Sample of the Study}

The community consisted of the estimated 11 commercial bank employees, operating in Irbid province, out of a total 34 branches Appendix A and a randomized judgmental sample were taken from (80) employees working in human resources departments. (71) resolutions deemed fit for analysis recovered. shown in Table 1.

Table-1. The personal characteristics for the study sample members.

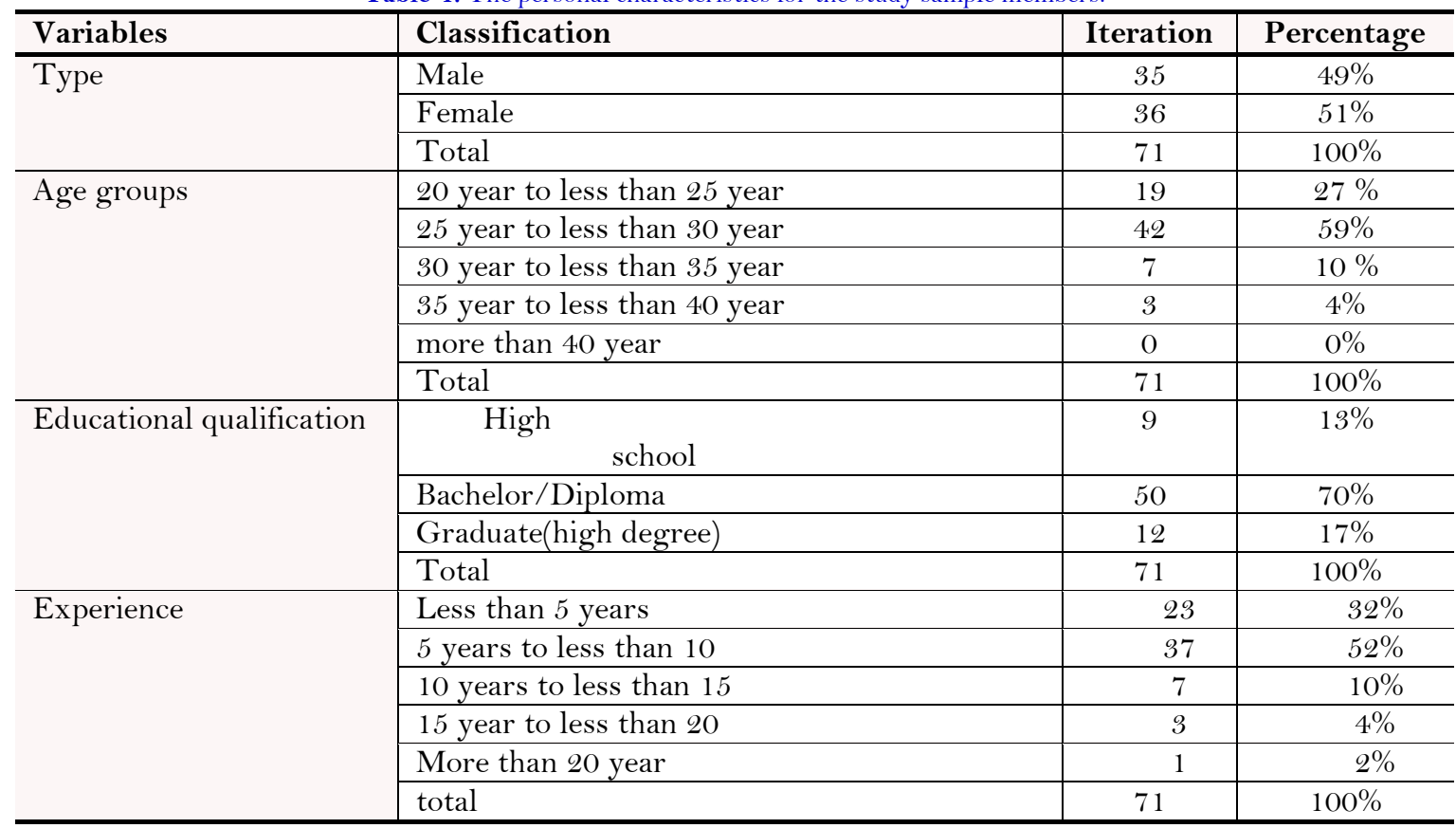

For the age groups of the sample, the table shows that the percentage of the age group 20 to less than 25 years of age was $27 \%$, and the age group 25 to less than 30 was $59 \%$. This indicates that the majority of the sample members are between the ages of 25 and 30. This indicates that most of the HR employees working in selected banks are young people. Who are usually enthusiastic and strongly motivated in their works? 
As for the educational qualification, the percentage of those holding a bachelor's and diploma about $70 \%$, while the percentage of those with higher degrees was $17 \%$. This indicates that most of the individuals whose working in HRM department in the banks are those who hold the first university degree.

In terms of the experience of working individuals in HRM, the percentage was $52 \%$ of individuals with less than 10 years of experience, while $2 \%$ only had experience of 20 years and more. This indicates that most of the individuals working in HRM department in the banks have good experience in the field of work, and therefore the competition for crisis management and the emergence of individuals working in those departments intensifies.

\subsection{The Tool of the Study}

The researcher developed a special questionnaire to identify the effects of human resources management practices in crisis management in the Jordanian commercial banks.

\subsection{The Honesty and Stability of the Tool}

The Cronbach's Alpha coefficient was used through the SPSS-Version-10 statistical package for internal consistency, with the result (86.3\%) This is an acceptable rate of stability, and Table 2 shows the internal consistency factor for all study variables.

Table-2. Kronbach alpha internal consistency factor for all study variables.

\begin{tabular}{l|c}
\hline The variable & Cronbach's Alpha coefficient \\
\hline Human Resources management Practices & $86 \%$ \\
\hline Crisis Management & $88 \%$ \\
\hline Controlling & $96 \%$ \\
\hline Motivation & $94 \%$ \\
\hline participation in decision making & $83 \%$ \\
\hline Training & $87 \%$ \\
\hline Detecting warning signal & $87 \%$ \\
\hline Preparedness and prevention & $81 \%$ \\
\hline Damage containment & $81 \%$ \\
\hline Reactivity & $91 \%$ \\
\hline Learning & $89 \%$ \\
\hline All variables & $86.3 \%$ \\
\hline
\end{tabular}

\section{THE THEORETICAL FRAMEWORK}

\subsection{Human Resources Practice}

Defined by Saleh [1] as the process of attracting and developing individuals, and maintaining them within the framework of achieving the objectives of the organization and achieving the goals of the employees.

And defined by Al-Ajami [6] as the administration that performs the administrative functions of obtaining, developing, compensating and maintaining individuals in order to achieve the objectives of the establishment.

Human resources management are one of the most important resources that the organization needs, other resources do not work, human resources are not involved, and human resources are part of the management of the affairs of the individuals working in terms of recruitment, qualification, training, development of competencies as well as the description of their work. Dessler defined it as "a set of practices and policies required to implement the various human-related activities that management needs to exercise its functions to the fullest. "The art of attracting, selecting and recruiting workers, developing their abilities and developing their skills, creating the right organizational conditions in terms of quantity and quality to extract their best energies and encourage them to exert as much effort and give as possible," he said. Aswathappa has known it as an administrative function that helps managers to attract, select, train and develop members of the organization, and human resources are concerned with the human dimension of the organizations. 
After reviewing the multiple concepts of human resources management, we see it as a series of procedures and foundations aimed at organizing individuals to get the maximum benefit from human competencies and extract their best energies through the functions of planning, polarization, selection, recruitment, training, evaluation, financial and moral incentives.

In the banking sector, human resources are one of the most valuable resources for banks. The Centre must work to provide the right number of staff in order to be able to carry out its mission to the fullest. It is necessary to write a job description that clearly defines the roles and responsibilities of each job, and the qualified individuals who have the appropriate amount of experience for their positions, must be prepared to prepare awareness of employees in health centers, and many health care workers need to receive training and awareness on how to deal with people with disabilities.

\subsubsection{Key Human Resources Management Activities}

\section{HR Planning.}

- Selection.

- Organization Structure.

- Training \& Development.

- Compensation \& Benefits.

- Performance Management.

- Employees Relation.

\subsubsection{Human Resources Management Functions: [7]}

1) Administrative functions: In which individual management is involved with other departments.

2) Specialized functions: performed solely by human resources management, including:

- Creating human resources: bringing in the human resources that are both quantitative and qualitative to accomplish the organization's work.

- Development and training of human resources: with the aim of increasing the efficiency of workers.

- Human resources reward: by raising wages, compensation, benefits and incentives.

- Integration and integration of human resources: by providing compatibility between management objectives and employees' objectives.

- Maintaining human resources: protecting them from the risks, accidents and diseases of work and protecting them from want and need after reaching retirement age.

\subsubsection{The Role of Human Resources Management Practices in Crisis Management}

Human resources management play an important role in organizations by helping them prepare their strategic plan that enables them to carry out their various tasks, such as providing appropriate information, both individually, collectively and at the enterprise level.

Human resources management can also contribute significantly to crisis management through [8].

a. Conduct an environmental survey to understand opportunities and threats.

b. Work to update and build a vision by linking the operations strategy to human resources department.

c. Encourages creative thinking, which helps to enhance and improve the brainstorming process by allowing easy sharing with the information needed.

d. Work to secure ideas to develop and find innovative solutions to crises.

\subsection{The Crisis}

A defect that materially affects the whole system and threatens the main assumptions underlying the system. 
The crisis is the ultimate result of the accumulation of a combination of influences or sudden disruption sits on the main components of the system and poses an explicit and clear threat to the survival of the organization or system itself.

\subsubsection{The Concept of Crisis}

There are many different concepts of the crisis and one meaning, which through its characteristics can be recognized.

According to Maher [9] the crisis is a defect that materially affects the whole system and threatens the main assumptions underlying the system, which is the ultimate result of the accumulation of a set of influences or the occurrence or sudden malfunction that affects the main components of the system and poses an explicit and clear threat to the survival of the organization or the system itself.

Simon, et al. [10] defined the crisis as a series of measures aimed at controlling a problem and reducing its aggravation so that it does not escape the lead to war". And Sultan [11] defined it as a position characterized by two basic elements:

A. Threat: The parties involved in the crisis feel that they will not be able to obtain or maintain the values, resources or objectives that are important to them.

B. Time pressure: The awareness of the parties involved in the crisis of the amount of time available to investigate the facts and take action before the onset of the occurrence or escalation of losses and the director's awareness of the time available to deal with the crisis is influenced by factors such as: complexity of the problem, level of diligence, and psychological pressure, if the more complex the problem the more the manager's sense of psychological pressure and the greater the sense of pressure of time and the less the degree of his response to the crisis.

While Salama and Beauty [12] say: that the concept of crisis lies in how to overcome it with different scientific administrative tools and avoid its disadvantages and benefit from positive side. By trying to figure out the difference between:

a. The problem: it is an obstacle or barrier that prevents the individual from achieving it, and expresses an event that has evidence and evidence that warns of a gradual occurrence not surprisingly, which helps to reach the best solution among several possible solutions and the relationship between the problem and the crisis is closely related, the problem may be the cause of the crisis but it will not be the crisis itself.

b. Crisis: It is a sudden and unexpected event which leads to the difficulty of dealing with it and therefore the need to look for ways and ways to manage the situation in a way that reduces its effects and negative consequences and also is a temporary state of disorder and imbalance of organization characterized by the inadequacy of the individual in confronting them using methods of solving problems.

c. Disaster: One of the concepts of sticking to crises is a devastating situation that has already occurred, and has caused damage, whether material or intangible, or together, and disasters are the causes of crises, but it is not a crisis in itself and disaster may have natural causes that have nothing to do with human beings.

\subsubsection{Characteristics of the Crisis [13]}

a. The violent surprise when it explodes.

b. The source of the crisis represents a major turning point in successive events in the life of the institution.

c. The crisis caused its beginning shock, and pressure, which weakens the possibility of rapid separation of its confrontation.

d. Crisis is characterized by changes in relations between the members of the organization.

e. The sudden escalation of the crisis leads to a high degree of uncertainty about the alternatives offered to face the conflicting events. 
f. The crisis threatens the stability of the institution and the components of the environment.

\subsubsection{Crisis Management Stages}

Dealing with crises is one of the focuses of attention in management, where dealing with crises requires a special type of managers who have many skills, including courage, fortitude, emotional balance, creativity, ability to communicate, dialogue, and the formulation and drawing of the necessary techniques to deal with the crisis.

\subsubsection{Most Writers and Researchers Agreed on the Five Stages of Crisis Management [9]}

Stage 1: Detection of warning signals:

It is represented by actions taken to reduce the causes of the crisis and reduce its risks, and this phase includes the early warning sensor that predicts the imminent occurrence of the crisis, and the early warning signals are a problem where managers receive many types of signals at the same time.

Stage 2: Readiness and Prevention:

They represent activities aimed at covering the potential and capabilities and training individuals and groups on how to deal with the crisis, and the foundation must have adequate preparations and methods for crisis prevention. In detecting weaknesses in the institution, treating them before they are exacerbated and difficult to treat.

\section{Stage 3: Damage containment}

To reduce the damage caused by the crisis, and to stop the chain of effects resulting from the crisis, and contain the effects of the crisis and minimize losses, it is necessary to isolate the crisis to prevent it from spreading in the rest parts of the institution.

\section{Stage 4: Reactivity}

The foundation must have long- and short-term plans to restore the situation before the crisis and restore activity levels, and this stage is a phase of rebalancing, requiring technical and administrative capabilities, great potential and financial support.

\section{Stage 5: Learning}

The learning stage includes important lessons learned by the institution from its previous experiences, as well as from the experiences of other institutions that are going through certain crises that the institution can go through, and we find a few institutions that are projecting: where the official works to cover his perception in the face of the crisis by focusing the spotlight on the defects of others and the shortcomings in their performance and often focuses on that he has warned them a lot of it.

\subsubsection{Crises Characteristics}

The most important characteristics of the crisis are Almagrabi and Jobta [14]:

1- The Violent surprise when it explodes.

2- The source of the crisis represents a major turning point in successive events in the life of the institution.

3- The crisis caused in its beginning shock and pressure, which weakens the possibility of rapid separation to confront it.

4- Characterized by changes in relations between the members of the organization.

5- The sudden escalation of the crisis leads to a high degree of uncertainty about the alternatives offered to face the conflicting events.

6- The crisis threatens the stability of the institution and the elements of the environment.

7- The response to the crisis requires unfamiliar organizational patterns, systems and innovative activities that enable the absorption and response of new circumstances resulting from sudden changes.

At the same time, Garavan [15] emphasizes on several sets of human resource development strategies, namely: 
a) those that focus on performance of the organization.

b) those who regard organizational learning and c) those aimed at the organizational change .

Most researchers agree that the strategic development of human resources implies systematical processes, formal ones, to be adapted to the needs at the organizational level. However, this development can help the organizational management to improve their operational abilities, meaning all the specific skills and competencies that allow a better management of the existing crises and also preventing future ones [16].

The organizations may face more difficulties on the operational capabilities, for example:

- The lack of adequate knowledge in crises' management [2].

- The lack of awareness regarding threats to business continuity [17].

- The inability to follow the respondents' instructions to the crisis when the incident occurs [18].

- The lack of psychological skills to cope and lack of decision-making skills [19].

\subsection{Previous Studies}

Manole, et al. [20] entitled: The Strategic Role of Human Resources Development in the Management of Organizational Crisis. The study aimed to examine the four major internal components of the organization strategy, structure, culture and leadership - in the strategic development of human capital, the latter having an essential role in dealing with crises that arise at the organizational level. The four dimensions are intertwined, being extremely important in terms of issues that arise at the organizational level, demonstrating the absolute influence over decision-making process by managers. The study found that a strategic development of human resources at the organizational level, has a major role in crisis management.

Thumiki, et al. [21] entitled: Resultant effect of crisis driven HR strategies applied during current economic crisis in Oman-An HR manager's perspective. This paper aims at identifying HR practices adopted during the current economic crisis in Oman, and explains the resultant effect of crisis-driven HR strategies from an HR managers' perspective. Primary data was collected online from 112 HR managers representing various manufacturing and service organizations in Muscat, Oman. It was found that HR managers perceive a greater impact of economic crisis on their businesses rather than other types of crises such as natural and technology crises. They think that managing employees during an economic crisis is relatively easier than managing other resources and other stakeholders. Knowledge management activities have been increased and non-monetary motivation techniques are being adopted as a part of crisis-driven HR management. Testing the hypothesis revealed that cost cutting on employee recreation is significantly higher in large organizations, job redesign activity is significantly higher in small organizations, while large organizations find it difficult to deal with employees during periods of crisis more so than small and medium sized organizations do.

Maryam, et al. [22] titled: Global financial Crisis Management by Human Resources Management. The paper investigate the effect of HR in alleviating worldwide money related emergency. They applied the enrolment and work profitability hypotheses which empower us direct our Search light on the example and procedures of HR the executives just as the relationship between HR the board and worldwide budgetary administration. The researchers emphasized that Certain steps must be taken to advance human asset the board that can counteract worldwide money related emergency, and speculation can be made on the job of HR the executives in relieving worldwide money related emergency. The main result was, incompetent and wasteful workers resulting in low output and profitability of employees and, in some situations, the collapse of such businesses, especially during the economic recession. HRM's position in preventing global economic meltdown cannot be over-emphasized,

Pelin [23] entitled: Strategic approach to human resources management during crisis. The study mainly focuses on the human resources strategies aspect of management at managing crises; and, it compares classical and modern ways to handle the effects of crises on human capital. The researcher found that the Policies related to crisis management can be classified as before crisis, during crisis and after crisis. Human resources plays an important 
part in the three phases of any crisis planning (before crisis), responding (during crisis), and recovery (after crisis). The human resources' role is more effective or vital before and after crisis periods. Furthermore, it is always essential that an organization keeps a place of safety and solace for its most valuable assets: employees.

Zulkarnaini, et al. [24] entitled: Crisis Management and Human Resource Development (HRD): An Integrated Conceptual Framework. The researchers highlight on HRD role and how it will offer a productive solution to enhance organizational crisis management $(\mathrm{CM})$. This study imply that with the emergence of diverse theoretical assumptions and philosophical paradigm, to manage potential or actual crisis event HRD might act as a central player in helping the organization to understand how such HRD interventions may support the crisis management in the organizations. The study found that each organization may encounter different kind of crisis, but intention of this study to suggest that HRD role should be taken as one of the important parts in crisis management initiatives.

Lositska and Bieliaieva [25] Entitled: HR Crisis Management at Trade Enterprises. The article is about revealing the content and role of $\mathrm{HR}$ crisis management at trade enterprises. The article provides an understanding of organizational changes, crisis phenomena, and crisis management. It is stated, that management of enterprises in a crisis state is one of the main problems of economy and legislation not only of economically developed countries, but also of countries with fragile economies. It is established, that as a result of a crisis, organizations may lose employees, workers, along with key talent and organizational knowledge, makers that employee's development and rewards are the major dimensions of the content of an Human Resource Management. It is proved, that an important factor that can contribute to effective crisis management is a well-selected, managed personnel, who respond quickly and flexibly to any changes in the environment.

Mitsakis and Aravopoulou [26] entitled: The Impact of the Economic Crisis upon Human Resource Development (HRD): Evidence from two Greek Banks. The study investigates the nature and changes of Human Resource Development (HRD) in two Greek banks under the challenging context of the economic crisis. It examines the latter's impact upon HRD as it was perceived from different stakeholders and through a pre and ongoing-crisis assessment approach. The study draws upon qualitative research data from two case study banking organizations in Greece, reporting on 76 semi-structured interviews with key stakeholders (HR staff, Bank Managers, employees) undertaken in 2014, six years after the fall of Lehman Brothers. The study contributes to academic knowledge as being the first empirical research offering a unique perspective through examining changes of HRD within a specific industry and national context (Greek banks) against a backdrop of an economic downturn. Its findings also raise important questions for HRD professionals, in both academia and practice, in relation to claims and aspirations which prevail in respect of HRD and organizational change and business transformation.

Through the review of previous studies it is clear that they agree in dealing with the subject of human resources management practices and their impact in crisis management, but they vary in addressing that effect, as evidenced by the amount of attention that researchers have given to human resources management practices, and it is also clear that each study started from a major problem different from the other, during which each researcher tried to reach results, due to different interests. Some studies have agreed with the current study on human resources management practices, although the current study dealt with the role of these practices in crisis management, which helps banks maintain their presence in the market. The current study also focus on the banking sector in Irbid under current difficult economic conditions.

\section{HYPOTHESES TESTING, RESULTS, AND RECOMMENDATIONS}

\subsection{Results Related to the Study's Main Question}

How well do the organization understand the importance of human resources management practices?

To answer this question, the researchers extracted the arithmetic averages and standard deviations of the study tool areas, as shown in the following Table 3: 
Table-3. Arithmetic averages and standard deviations of study tool areas are ranked downwardly

\begin{tabular}{c|c|c|c}
\hline Standard Deviation & Arithmetic Average & The variables & No. \\
\hline .60 & 4.20 & Participation in Decision Making & 1. \\
\hline .69 & 4.07 & Controlling & 2. \\
\hline .48 & 3.86 & Motivation & 3. \\
\hline .59 & 3.76 & Training & 4. \\
\hline .45 & 3.96 & All variables & 5. \\
\hline
\end{tabular}

Table 3 shows that the arithmetic averages of the variables of study came high, where the variable participation in decision-making came first with arithmetic average of 4.2 followed, by the variable the controlling with an average of 4.07 , while in the last place the variable training came with arithmetic average of 3.76.

\subsubsection{Calculation Averages and Standard Deviations of the Study Area Paragraphs Were Also Extracted, as Follows}

\section{First: Participation in Decision-Making}

The results presented in Table 4 show that the arithmetic average for all paragraphs (4.20) and standard deviation (0.92), indicating that the Jordanian bank workers are positive for the paragraphs that measured the participation in decision making, as all averages of phrases were higher than the standard average (3). The paragraph " Managers consult those with lower degrees of functionality before making a decision " came first with arithmetic average (4.35), and the paragraph " The Bank allows employees to participate in decision-making " with a arithmetic average (3.85) came last. The standard deviation values of all paragraphs came Converging and did not indicate differences in the opinions of the study sample.

Table-4. Participation in decision-making.

\begin{tabular}{c|c|l}
\hline \multicolumn{2}{c}{ Table-4. Participation in decision-making. } \\
\hline 1.01 & $\begin{array}{c}\text { Arithmetic } \\
\text { Average }\end{array}$ & Paragraphs \\
\hline 0.87 & 4.35 & $\begin{array}{l}\text { Managers consult those with lower degrees of functionality before } \\
\text { making a decision }\end{array}$ \\
\hline 1.04 & 4.32 & Management has clear foundations in the decision-making process \\
\hline 0.90 & 4.28 & Management trains staff to make decisions \\
\hline 0.84 & 4.25 & The decision-making process is rational and conscious \\
\hline 0.89 & 4.25 & The decision-making process is conducted on a scientific basis \\
\hline 1.08 & 4.08 & All employees seek to rationalize decision-making processes \\
\hline 0.92 & 3.85 & The Bank allows employees to participate in decision-making \\
\hline & 4.20 & Arithmetic average and standard deviation of all paragraphs \\
\hline
\end{tabular}

\section{Second: Controlling}

The results presented in Table 5 show that the arithmetic average for all paragraphs (4.07) and standard deviation (0.89), indicating that the Jordanian bank workers are positive for the paragraphs that measured the participation in decision making, as all averages of phrases were higher than the standard average (3).

Table-5. Controlling.

\begin{tabular}{c|c|l}
\hline Standard deviation & $\begin{array}{c}\text { Arithmetic } \\
\text { Average }\end{array}$ & Paragraphs \\
\hline 0.96 & 4.35 & The regulatory process produces positive and stimulating results \\
\hline 0.96 & 4.32 & Oversight officers seek correction, not punishment \\
\hline 1.02 & 4.28 & The control process is well done and feasible. \\
\hline 1.07 & 4.25 & There are controls at all levels of management \\
\hline 1.08 & 4.25 & The control system follows modern control methods \\
\hline 1.14 & 4.08 & The regulatory process produces positive and stimulating results \\
\hline 0.89 & 3.85 & Arithmetic average and standard deviation of all paragraphs \\
\hline
\end{tabular}


The paragraph " The regulatory process produces positive and stimulating results" came first with arithmetic average (4.35), and the paragraph " The regulatory process produces positive and stimulating results " with a arithmetic average (3.83) came last. The standard deviation values of all paragraphs came Converging and did not indicate differences in the opinions of the study sample

\section{Third: Motivation}

The results presented in Table 6 show that the arithmetic average for all paragraphs (3.86) and standard deviation (0.96), indicating that the Jordanian bank workers are positive for the paragraphs that measured the participation in decision making, as all averages of phrases were higher than the standard average (3). The paragraph " Administrative empowerment gives employees an opportunity to demonstrate their abilities " came first with arithmetic average (4.16), and the paragraph " Management relies on empowering employees to be willing to take on responsibilities " with a arithmetic average (3.52) came last. The standard deviation values of all paragraphs came Converging and did not indicate differences in the opinions of the study sample.

Table-6. Motivation

\begin{tabular}{c|c|l}
\hline Standard deviation & $\begin{array}{c}\text { Arithmetic } \\
\text { Average }\end{array}$ & Paragraphs \\
\hline 0.95 & 4.16 & $\begin{array}{l}\text { Administrative empowerment gives employees an opportunity to } \\
\text { demonstrate their abilities }\end{array}$ \\
\hline 0.92 & 4.11 & Employees do their job well when motivated \\
\hline 1.00 & 3.98 & When motivated, employees feel high confidence \\
\hline 1.06 & 3.91 & $\begin{array}{l}\text { Motivating employees pushes them to innovate and develop } \\
\text { working methods }\end{array}$ \\
\hline 1.15 & 3.74 & $\begin{array}{l}\text { Management encourages employees to take responsibility by } \\
\text { motivating them }\end{array}$ \\
\hline 1.08 & 3.59 & $\begin{array}{l}\text { Motivation helps employees achieve promotion to a higher } \\
\text { position }\end{array}$ \\
\hline 1.18 & 3.52 & $\begin{array}{l}\text { Management relies on empowering employees to be willing to } \\
\text { take on responsibilities }\end{array}$ \\
\hline 0.96 & 3.86 & \begin{tabular}{l} 
Arithmetic average and standard deviation of all paragraphs \\
\hline
\end{tabular}
\end{tabular}

\section{Forth: Training}

The results presented in Table 7 show that the arithmetic average for all paragraphs (3.76) and standard deviation (0.95), indicating that the Jordanian bank workers are positive for the paragraphs that measured the participation in decision making, as all averages of phrases were higher than the standard average (3). The paragraph " All employees are given the same career interest " came first with arithmetic average (4.14), and the paragraph " Managers take into account the right times in the training process " with a arithmetic average (3.38) came last. The standard deviation values of all paragraphs came Converging and did not indicate differences in the opinions of the study sample.

Table-7. Training.

\begin{tabular}{c|c|l}
\hline Standard deviation & $\begin{array}{c}\text { Arithmetic } \\
\text { Average }\end{array}$ & Paragraphs \\
\hline 1.00 & 4.14 & All employees are given the same career interest \\
\hline 1.07 & 3.85 & $\begin{array}{l}\text { Employees are committed to training programs and their } \\
\text { application at work }\end{array}$ \\
\hline 0.90 & 3.84 & \begin{tabular}{l} 
Employees receive appropriate training programs \\
\hline 0.98
\end{tabular} \\
\hline 1.11 & 3.46 & $\begin{array}{l}\text { The Bank's training and development department aims to raise } \\
\text { efficiency }\end{array}$ \\
\hline 1.15 & 3.38 & $\begin{array}{l}\text { Managers take into account the psychological state of the staff } \\
\text { when designing training }\end{array}$ \\
\hline
\end{tabular}


9.1.2. Hypothesis Testing

The researcher used the a (NOVA) analysis to test the hypotheses of the study, by selecting $(\mathrm{P})$, where the hypothesis is accepted if the calculated $(\mathrm{P})$ value is less than the p-value of the scheduled, and rejects the hypothesis if the calculated $(\mathrm{P})$ value is greater than the p- value of the scheduled. And the coefficient test. The following are the results of the hypotheses test.

\subsubsection{The Main Hypothesis}

The main hypothesis: There is no statistically significant effect for the human resources management practices (training, participation in decision-making, motivation, controlling) in the ability of Jordanian commercial banks in manage crises (Readiness and prevention, damage containment, Reactivity, Learning).

Table-8a. Coefficient Analysis of the Main Hypothesis.

\begin{tabular}{l|l|l|l|l}
\hline Model & R & R square & Adjust R square & Std. error of the estimate \\
\hline 1 & $0.801 \mathrm{a}$ & 0.635 & 0.641 & 0.3141 \\
\hline $\begin{array}{l}\text { Note: } \\
\text { a. constant: crisis management b. variable: Human resources management practices. }\end{array}$
\end{tabular}

Table-8b. Results of the main hypothesis test.

\begin{tabular}{c|c|c|c|c|c}
\hline & Sum of Squares & df & Mean square & F & Sig \\
\hline Between Groups & 35.336 & 25 & 1.702 & 660.620 & 00.0 \\
\hline Within groups & 119 & 46 & 002. & & \\
\hline Total & 35.440 & 71 & & & \\
\hline
\end{tabular}

Table 8a showing that the (coefficient) was (0.635) and that the Human Resources Practices were interpreted by $(64 \%)$ of the disparity in crisis management. It is also found that in Table $8 \mathrm{~b}$ the calculated value of $(\mathrm{P})$ was 660.620 , which is greater than the scheduled $(\mathrm{P})$ value of 4.00 at a degree of confidence $(0.95 \%)$ and moral $(0.05>\mathrm{a})$, where it was found that there is a statistical indication for the Human Resources Practices on the crisis management in Jordanian commercial banks.

\section{The First Hypothesis}

Hypothesis 1: there is no statistically significant effect for the training in the ability of Jordanian commercial banks in manage crises.

Table-9a. Coefficient Analysis of the First Hypothesis.

\begin{tabular}{|c|c|c|c|c|}
\hline Model & $\mathbf{R}$ & R square & Adjust $\mathrm{R}$ square & Std. error of the estimate \\
\hline 1 & $0.760 \mathrm{a}$ & 0.740 & 0.613 & 0.410 \\
\hline
\end{tabular}

Table-9b. Results of the First Hypothesis.

\begin{tabular}{l|c|c|c|c|c}
\hline & Sum of Squares & df & Mean square & F & Sig \\
\hline Between Groups & 34.351 & 27 & 2.23 & 434.22 & 00.0 \\
\hline Within groups & 1.15 & 44 & .017 & & \\
\hline Total & 35.501 & 71 & & & \\
\hline
\end{tabular}

Table 9a showing that the (coefficient) was (0.740) and this mean that the training has been interpreted by $(61 \%)$ From the variation in crisis management, the result indicate in Table $9 \mathrm{~b}$ that the calculated $(\mathrm{P})$ value was 243,000 and is greater than the $(\mathrm{P})$ scheduled value of 4.00 at a confidence score $(0.95 \%)$. According to this finding, 
I reject the first hypothesis. In other words, there is a statistically significant effect for the training in the ability of Jordanian commercial banks in manage crises.

\section{The Second Hypothesis}

There is no statistically significant effect for the participation in decision making in the ability of Jordanian commercial banks in manage crises.

Table-10a. Coefficient analysis of the second hypothesis.

\begin{tabular}{l|c|c|c|c}
\hline Model & $\mathbf{R}$ & $\mathbf{R}$ square & Adjust R square & Std. error of the estimate \\
\hline 1 & $0.508 \mathrm{a}$ & 0.621 & 0.531 & 0.411 \\
\hline Note:
\end{tabular}

a. constant: crisis management.

b. variable: Participation in decision making.

Table-10b. Results of second hypothesis

\begin{tabular}{c|c|c|c|c|c}
\hline & Sum of Squares & df & Mean square & F & Sig \\
\hline Between Groups & 16.902 & 5 & 4.220 & 96.453 & 00.0 \\
\hline Within groups & 2.891 & 66 & .044 & & \\
\hline Total & 19.793 & 71 & & & \\
\hline
\end{tabular}

Table 10a showing that the (coefficient) was 0.621 , which means that the participation in decision making has been interpreted (53\%) From the variation in crisis management, the results indicate in Table 10b that the computerized $(\mathrm{P})$ value was 96.453 and is greater than the $4.00(\mathrm{p})$ table value at a confidence score $(0.95 \%)$. According to this finding, I reject the second hypothesis. In other words, there is a statistically significant effect for the participation in decision making in the ability of Jordanian commercial banks in manage crises.

\section{The Third Hypothesis}

There is no statistically significant effect for the motivation in the ability of Jordanian commercial banks in manage crises.

Table-11a. Analysis of the coefficient of the third hypothesis.

\begin{tabular}{c|c|c|c|c}
\hline Model & $\mathbf{R}$ & R square & Adjust R square & Std. error of the estimate \\
\hline 1 & $0.924 \mathrm{a}$ & 0.854 & 0.845 & 0.209 \\
\hline Note: & \multicolumn{4}{|c|}{ Table-11a. Analysis of the coefficient of the third hypothesis. } \\
\hline
\end{tabular}

a. constant : crisis management

b. variable: Motivation.

Table-11b. Results of third hypothesis.

\begin{tabular}{c|c|c|c|c|c}
\hline & Sum of Squares & df & Mean square & F & Sig \\
\hline Between Groups & 34.311 & 17 & 3.125 & 96.453 & 00.0 \\
\hline Within groups & 2.221 & 54 & .119 & & \\
\hline Total & 36.532 & 71 & & & \\
\hline
\end{tabular}

Table 11a showing that the (coefficient) was 0.854 , which means that the Motivation has been interpreted by $(84 \%)$ From the variation in crisis management, the results indicate in Table $11 \mathrm{~b}$ that the calculated $(\mathrm{P})$ value was 191.645 and is greater than the $(\mathrm{P})$ scheduled value of 4.00 at a confidence score $(0.95 \%)$ And moral $(\mathrm{a}<0.05)$. According to this finding, I reject the third hypothesis. In other words, there is a statistically significant effect for the motivation in the ability of Jordanian commercial banks in manage crises.

\section{The Forth Hypothesis}

There is no statistically significant effect for Controlling in the ability of Jordanian commercial banks in manage crises. 
Table-12a. Coefficient analysis of the fourth hypothesi.

\begin{tabular}{|c|c|c|c|c|}
\hline Model & $\mathbf{R}$ & R square & Adjust R square & Std. error of the estimate \\
\hline 1 & $0.710 a$ & 0.505 & 0.494 & 0.0824 \\
\hline
\end{tabular}

Table-12b. Results of fourth hypothesis.

\begin{tabular}{c|c|c|c|c|c}
\hline & Sum of Squares & df & Mean square & F & Sig \\
\hline Between Groups & 28.910 & 34 & 4.228 & 96.132 & 00.0 \\
\hline Within groups & 1.152 & 37 & .033 & & \\
\hline Total & 30.062 & 71 & & & \\
\hline
\end{tabular}

Table 12a showing that the (coefficient) was 0.505 , which means that the Learning was interpreted by (49\%) From the variation in crisis management where the results indicate in the Table $12 \mathrm{~b}$ that the calculated value of $(\mathrm{P})$ was 96.132 which is greater than the $(\mathrm{P})$ scheduled value of 4.00 at a confidence score $(0.95 \%)$ And moral $(\mathrm{a}<0.05)$. According to this finding, I reject the fourth hypothesis. In other words, There is a statistically significant effect for Controlling in the ability of Jordanian commercial banks in manage crises.

9.2. Results

1) The results of the study generally showed a statistically significant influence for the human resources management practices (training, participation in decision-making, motivation, controlling) in the ability of Jordanian commercial banks in manage crises (Readiness and prevention, damage containment, Reactivity, Learning).

2) The results of the study showed a statistically significant influence for the Training in management of crisis. where the nature of the bank's work depends on HR management practices, and the Banks adopts special programs in encounter the crises, further more the current HR staff compares between previous crises stored, which enhances and helps works on the good management of crises among workers. and showed that the training contributes to the development of the capabilities of the bank's employees. The Banks are opening the way for employees to attend external training courses, and they have no difficulty in applying the working methods they have been trained, thus creating a sense of competition and providing better and increasing their ability to manage the crisis.

3) The results of the study showed a statistically significant influence for Participation in decision making, and their role in crisis management, and the HR participation help in the speed of retrieving information, the members of the sample believe that the banks uses a skill HR staff that fit the nature of work to cope with the variables in the changing working environment.

4) The results of the study showed a statistically significant influence for the Motivation system and its in crisis management, and the members of the sample believe that the Motivation system used in the bank is flexible. The necessary adjustments to the characteristics of the programs used enable to cope with developments, and could be easily made. which enhances and supports knowledge sharing among workers and motivates them to manage the crisis effectively.

5) The results of the study showed a statistically significant influence for the Controlling system and its in crisis management, and the members of the sample believe that the Controlling system used in the bank is strong and stable. 
1. Establishment of a crisis management team. HR has an integral role in the crisis management.

2. having the required talent and succession plans in place to ensure that the necessary work of the organization can continue.

3. Outsourcing like consultants is another option, consultant that can lead the process.

4. Develop recovery plans. These strategies should address the safety, health and welfare of employees before, during and after an emergency.

5. Helping employees achieve a sense of normalcy. is also an important factor in addressing the human side of a crisis to be most effective.

6. Leading the discussion about the future of the organization's workforce is an obvious way for HR to contribute to crisis management.

7. Communication. During a crisis, employees and other internal stakeholders need a convenient through identifying the most critical issues that could influence the workforce for the coming years.

Funding: This study received no specific financial support.

Competing Interests: The authors declare that they have no competing interests.

Acknowledgement: All authors contributed equally to the conception and design of the study.

\section{REFERENCES}

[1] H. A. Saleh, Resources and its development (Foundations and applications on the Arab world), 1st ed. Amman: Jordan University, 2002 .

[2] L. Sayegh, W. P. Anthony, and P. L. Perrewé, "Managerial decision-making under crisis: The role of emotion in an intuitive decision process," Human Resource Management Review, vol. 14, pp. 179-199, 2004.

[3] M. Sahnoon, Economic of monetary and banking, 1 st ed. Qusantina, Jazaer: Bahaa Aldeen for Publishing and Distributing, 2003.

[4] D. M. Peterson and R. W. Perry, "The impacts of disaster exercises on participants," Disaster Prevention and Management, vol. 8, pp. 241-255, 1999.Available at: https://doi.org/10.1108/09653569910283879.

[5] U. Sekaran and R. Bougie, Research methods for business. A skill-building approach, 5th ed. New York: John Wiley\&Sons Inc, 2010

[6] M. Al-Ajami, Recent trends in management leadership and human development, 2nd ed. Amman-Jordan: Dar Almasira for Distribution and Publishing, 2010.

[7] H. A. Saleh, Resources and its development (Foundations and applications on the Arab world), 2nd ed. Amman: Jordan University, 2006

[8] S. Mckie. (2004) Practical tools for new ideas. Intelligent Enterprise Magazine.

[9] A. Maher, Crisis management. Alexandria: University House, 2006.

[10] M. Simon, B. Elango, S. M. Houghton, and S. Savelli, "The successful product pioneer: Maintaining commitment while adapting to change," Journal of Small Business Management, vol. 40, pp. 187-203, 2002.

[11] I. Sultan, Administrative information systems, access to systems. Alexandria: University House, 2000.

[12] M. Salama and I. Beauty, Disaster planning and confrontation. Cairo: Mubarak Academy of Security - Police College, 2007.

[13] S. Fink, Crisis management: Planning for inheritable. New York: AMACOM, 1986.

[14] A. Almagrabi and B. Jobta, The innovation management in millennium. Cairo, Egypt: Dar Alfajr for Publishing and Distributing, 2008.

[15] T. N. Garavan, "A strategic perspective on human resource development," Advances in Developing Human Resources, vol. 9, pp. 11-30, 2007.

[16] J. Wang, "Exploring the strategic role of human resource development in organizational crisis management," Texas Aङ M University, vol. 8, pp. 22-53, 2016. 
[17] J. M. Dahlhamer and M. J. D’Souza, "Determinants of business disaster preparedness in two U.S. metropolitan areas," International Journal of Mass Emergencies and Disasters, vol. 15, pp. 265-281, 1997.

[18] R. W. Perry and L. D. Mankin, "Preparing for the unthinkable: Managers, terrorism and the HRM function," Public Personnel Management, vol. 34, pp. 175-193, 2005.

[19] A. Gaudine and L. Thorne, "Emotion and ethical decision-making in organizations," Journal of Business Ethics, vol. 31 , pp. 175-187, 2001.

[20] C. Manole, C. Alpopi, and S. E. Colesca, "The strategic role of human resources development in the management of organizational crisis," Economy. Seria Management, vol. 14, pp. 207-221, 2011.

[21] V. R. R. Thumiki, A. Jovancai-Stakić, and B. R. S. S. Al, "Resultant effect of crisis-driven HR strategies applied during current economic crisis in Oman: An HR manager's perspective," The European Journal of Applied Economics, vol. 16, pp. 77-98, 2019.Available at: https://doi.org/10.5937/ejae15-19262.

[22] Maryam, A. Rachma, S. Eko, O. Dwi, and Riinawati, "Global financial crisis management by human resources management," Journal of Critical Revieres, vol. 7, pp. 287-290, 2020.

[23] V. Pelin, "Strategic approach to human resources management during crisis," presented at the 12th International Strategic Management Conference, ISMC 2016, 28-30 October 2016, Antalya,Turkey, 2016.

[24] N. A. S. Zulkarnaini, R. Shaari, and A. Sarip, "Crisis management and human resource development: Towards research agenda," Advances in Human Factors, Business Management and Leadership, vol. 961, pp. 542-552, 2020.Available at: http://doi.org/10.1007/978-3-030-20154-8_50.

[25] T. Lositska and N. Bieliaieva, "Hr crisis management at trade enterprises," EUREKA: Social and Humanities, vol. 1, pp. $10-15,2020$.

[26] F. V. Mitsakis and E. Aravopoulou, "The impact of the economic crisis upon human resource development (HRD): Evidence from two Greek banks," International Journal of Human Resource Development: Practice, Policy ङ Research, vol. 1, pp. 67-82, 2016.Available at: https://doi.org/10.22324/ijhrdppr.1.117.

Appendix-a. Names of the banks surveyed.

\begin{tabular}{c|c}
\hline Number of branches in the Northern region & Names of the banks surveyed \\
\hline 5 & Arab bank \\
\hline 6 & Housing bank for trade and finance \\
\hline 3 & Jordan ahli bank \\
\hline 6 & Bank of Jordan \\
\hline 4 & Cairo Amman bank \\
\hline 3 & Jordan Kuwait bank \\
\hline 2 & Arab Jordan Investment bank \\
\hline 2 & Jordan Commercial bank \\
\hline 1 & Societe generale de banque \\
\hline 1 & Citibank \\
\hline 1 & Capital bank of Jordan \\
\hline
\end{tabular}

Views and opinions expressed in this article are the views and opinions of the author(s), Journal of Asian Scientific Research shall not be responsible or answerable for any loss, damage or liability etc. caused in relation to/arising out of the use of the content. 